has suffered a stroke, venous thrombosis, or heart attack. Factor V Leiden may coexist with hereditary homocystinuria, another prothrombotic disorder.

The role of hyperhomocysteinemia in stroke is emphasized in a study of 125 consecutive adults at the University of Munster, Germany. (Evers S, Koch H-G, Grotemeyer K-H et al. Features, symptoms, and neurophysiological findings in stroke associated with hyperhomocysteinemia. Arch Neurol Oct 1997;54:1276-1282). The prevalence was 20\% in all patients with stroke, and impaired cognition was more pronounced in those with hyperhomocysteinemia.

\title{
INFECTIOUS DISORDERS
}

\section{CAT-SCRATCH ENCEPHALOPATHY}

A 9-year-old girl with cat-scratch disease complicated by encephalopathy and seizures is reported from the Kaiser Foundation Hospital, Los Angeles, CA. The patient was admitted to hospital after a 2-week history of cervical adenitis, a 2-day history of low-grade fever, diarrhea, and headache, and an 11-day course of oral antibiotics with no response. A generalized tonicclonic seizure occurred within hours of admission and initiation of i.v. antibiotics. Following the 2 minute seizure she became combative, delirious, and comatose. CSF showed protein of $72 \mathrm{mg} / \mathrm{dl}$ and normal cells. Recovery began after 24 hours and was complete in 5 days. Serum serology and polymerase chain reaction (PCR) analysis of lymph node tissue were positive for Bartonella henselae. The child had 4 kittens but no observed scratches or bites. (Wheeler SW, Wolf SM, Steinberg EA. Cat-scratch encephalopathy. Neurology Sept 1997;49:876-878). (Reprints: Dr Sheldon M Wolf, 1505 N Edgemont Street, 5th Floor, Los Angeles, CA 90027).

COMMENT. Neurologic complications of cat-scratch disease are uncommon, although there are several reports of encephalopathy, generally with complete recovery, and isolated reports of myelopathy, cranial nerve palsies, optic neuritis, chorea, and cerebellar ataxia. A cat scratch is not always identified, but the cat is the principal reservoir for the infecting organism, Bartonella henselae. A cat flea may account for the transmission in some cases. See Progress in Pediatric Neurology II (Millichap JG, ed. Chicago, PNB Publishers, 1994;pp421-423) for further reports of neurologic complications of cat-scratch disease, including one series of 76 patients. The differential diagnosis includes Lyme encephalitis.

\section{FACIAL PALSY AND LYME BORRELIOSIS}

The value of CSF examinations for intrathecal antibody production to Borrelia burgdorferi in the diagnosis of neuroborreliosis in children with peripheral facial palsy (PFP) was examined at the University Children's Hospital of Zurich, Switzerland. Twenty (95\%) of the children with PFP had immunoglobulin (Ig)M or IgG in the acute-phase serum, but serologic assays showed discrepancies in one third. Intrathecal antibody to B. burgdorferi was present in 5 of the 20 seropositive children. Seroconversion in convalescent sera was found in all 5 with intrathecal antibody, and in 8 of 10 without intrathecal specific-antibody production. Patients showing intrathecal antibodies or seroconversion had lymphocytic pleocytosis in the acute phase of PFP. (Albisetti M, Schaer G, Good M, Boltshauser E, Nadal D. Diagnostic value of cerebrospinal fluid examination in children with peripheral facial palsy 